\title{
Severo Ochoa (1905-1993): The man behind RNA
}

\author{
Siang Yong $\underline{T a n}^{1}, \mathrm{MD}, \mathrm{JD}$, Kate Pettigrew ${ }^{2}$
}

0

evero Ochoa de Albornoz was a Spanish biochemist and enzymologist who won the 1959 Nobel Prize for the synthesis of ribonucleic acid (RNA).

CATALYST Ochoa, the youngest of seven children, was born in Luarca, Spain, on 24 September 1905. His namesake and father, Severo Ochoa, was a lawyer-businessman who suffered an early death of unknown cause. This meant that the young boy, his mother and his six siblings needed to find a new life and home in Málaga, Spain. Although the tragedy and relocation were difficult for the family, many believe that this early challenge helped to spark Ochoa's independent passion for education and learning. He mastered French mostly by himself and spent his younger years trying to help the family, given the health problems of his widowed mother. Ochoa's early education remains under debate: some sources, including the Nobel Prize biography, report that he was educated at Málaga College and earned his Bachelor of Arts degree in 1921, at the age of 17. However, other sources say that the school Ochoa attended was actually a high school and that a misunderstanding had originated from its Spanish name (Instituto de Bachillerato de Málaga).

\section{NOB E L L A UR E A T E S APLENTY Ochoa's interest in} biology was stimulated by the work of Spanish Nobel laureate Santiago Ramón y Cajal, who studied the structure of the nervous system. Ochoa attended the medical school of the University of Madrid in 1923, hoping to

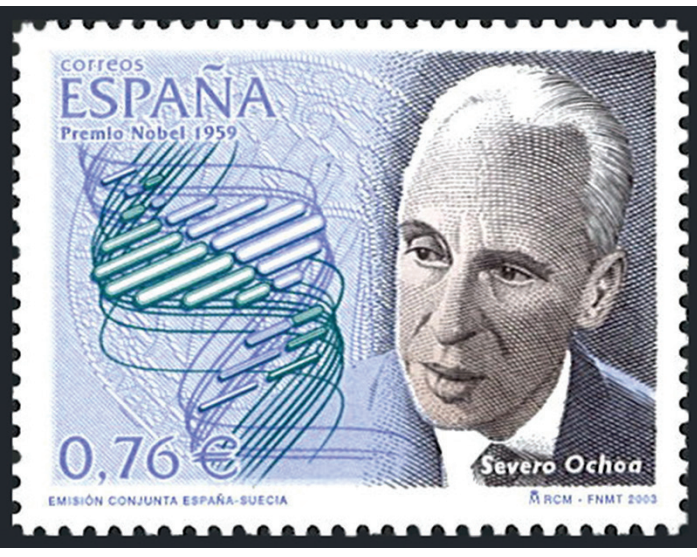

Biological Chemistry. It was a proud moment for him, given his youth and the fact that English was not his native language, and he is said to have reminisced about this accomplishment frequently.

During medical school, Ochoa lived in the well-known Residencia de Estudiantes in Madrid amidst many aspiring artistic and scientific marvels, including painter Salvador Dali and poet Federico García Lorca. There were frequent lectures by Nobel laureates such as Marie Curie and Albert Einstein during the time Ochoa lived there. After obtaining his medical degree with honours in 1929, Ochoa, at age 24, applied for a fellowship position at Otto Meyerhof's laboratory in Berlin, Germany, which was at the cutting edge of the new discipline of biochemistry. There, he interacted with many famous biochemists such as Dr Otto Warburg and Dr Fritz Lipmann. Meyerhof, famous for his Embden-Meyerhof pathway in glycolysis, by which glucose is converted to pyruvic acid with production of adenosine triphosphate (ATP), had himself won the Nobel Prize less than a decade earlier. That same year, Ochoa made a trip to Boston to attend the International Congress of Physiology and visited several places in the United States (US), where one of his brothers was living. Upon his return to Spain in 1930, he resumed work at the Residencia de Estudiantes to complete research for his Doctor of Medicine thesis.

In 1931, Ochoa twice fell in love. The first was with a woman by the name of Carmen García Covián, whom he married. The second was with enzymology, which he discovered while working as a work with Dr Cajal, but the latter had retired by that time. Although the medical school itself housed no research facilities, Ochoa was able to expand his academic and scientific potential. Being a top student, Ochoa and his talent were quickly noted by the university's professor of physiology, Dr Juan Negrín, who regularly selected brilliant students as his laboratory assistants. Ochoa was initially given the rather routine task of isolating creatinine from urine. He also developed a method for measuring muscle creatinine. During the summer of 1927, when Ochoa was still a fourth-year medical student, he travelled to Glasgow, Scotland, to work with Dr Noel Paton to improve the assay for creatinine and his command of English. Within a short time, he was able to publish his first scientific note in the Proceedings of the Royal Society, and upon his return to Madrid, he and fellow student José Valdecasas submitted a paper to the prestigious Journal of postdoctoral fellow with Dr H W Dudley in the laboratory of Sir Henry Dale in England, yet another Nobel Prize winner, for his research on acetylcholine. Departing from his earlier work on muscle creatinine, Ochoa ventured into the world of enzymes and their role in intermediary metabolism. It was a turning point in his career and became his lifelong interest. His first introduction was an enzyme called glyoxalase, whose primary function is to detoxify substances such as methylglyoxal and other aldehydes. These compounds are byproducts of normal living biochemical processes but highly toxic to cells. The remarkable enzyme that captured Ochoa's attention in 1931 would go on to be targeted by pharmaceutical companies decades later to create antibiotics and anticancer drugs. But for Ochoa, glyoxalase was a steppingstone to the prolific biochemical discoveries that soon followed, particularly his work on nucleic acids and RNA.

${ }^{1}$ Emeritus Professor of Medicine, University of Hawaii, ${ }^{2}$ Research carried out as a medical student at the John A Burns School of Medicine, University of Hawaii, Honolulu, USA Correspondence: Prof Tan Siang Yong, 2226 Liliha Street, Suite B-104, Honolulu, HI 96817, USA. siang@hawaii.edu 
HIGH-ENERGY RESEARCH In 1933, the Ochoas returned to Madrid, where he began to study glycolysis in heart muscle. Ochoa's research increasingly focused on enzymatic processes and the transfer of energy. He described many of the basic steps of carbohydrate and fatty acid metabolism, carbon dioxide utilisation, and nucleic acid synthesis. For example, he was one of the first to demonstrate the important role of highenergy phosphates, such as ATP, in the storage and release of energy. While investigating oxidative phosphorylation, in which parties of three phosphates split apart and release hidden energy, Ochoa discovered something even more powerful: the enzyme polynucleotide phosphorylase, affectionately known as PNPase. PNPase plays a crucial role in the synthesis of RNA by assisting with messenger RNA processing and degradation. This 'chemical blueprint for a protein product' is transcribed from a deoxyribonucleic acid (DNA) template and carries coding information to the sites of protein synthesis, the building block of all living things. Ochoa's discovery of this critical enzyme was later used for the synthesis of artificial RNA and the breaking of the human genetic code. For this discovery, he was awarded the 1959 Nobel Prize in Physiology or Medicine, sharing it with Arthur Kornberg, who synthesised DNA.

MOVE TO THE US In 1936, the Spanish Civil War erupted, and Ochoa chose to return to Meyerhof's Kaiser Wilhelm Institute for Biology. The institute was now located in Heidelberg, Germany, and was focused not only on glycolysis, but also on the enzymology of yeast fermentation. From 1938 to 1941, he was Demonstrator and Nuffield Research Assistant at the University of Oxford, England. In 1942, Ochoa immigrated to the US, mostly upon his wife Carmen's urging, to work at New York University, and became an American citizen in 1956. He rose from Research
Associate in Medicine at the New York University School of Medicine to Chairman of its Department of Biochemistry.

Ochoa's other accomplishments included the isolation of several enzymes catalysing steps of the Krebs cycle, as well as the biological functions of Vitamin B1. For his many scientific accomplishments, he was awarded some 30 honorary degrees from universities across the world, including in Glasgow, Oxford, Salamanca and Brazil. Ochoa was an Honorary Professor at the University of San Marcos, Lima, Peru, and was awarded the Neuberg Medal in Biochemistry in 1951. In 1959, the year that he won the Nobel Prize, he was also honoured with the Medal of the Société de Chimie Biologique and the Medal of New York University. To showcase his remarkable impact on the world of science, the asteroid 117435 Severochoa was named in his honour. He was also a recipient of the US National Medal of Science in 1978.

Ochoa retired from New York University at the age of 69, then moved to the Roche Institute of Molecular Biology, where he stayed until he was 80 . In 1985, he finally left academia and returned to Spain to serve as an advisor to Spanish science policy authorities and scientists. Ochoa died in Madrid, Spain, on 1 Nov 1993 at age 88, in the clinic of Dr Carlos Jiménez Diaz, a professor and longtime friend.

\section{BIBLIOGRAPHY}

- Dubinsky E; Bernard Becker Medical Library, Washington University School of Medicine. Severo Ochoa (1905-1993). In: Medical Journeys [online]. Available at http://beckerexhibits.wustl.edu/mig/bios/ochoa.html. Accessed April 10, 2010.

- Grisolia S. The tenth anniversary of the death of Severo Ochoa. IUBMB Life 2004; 56:55-7.

- Ochoa S, Valdecasas JG. A micromethod for the estimation of total creatinine in muscle. J Biol Chem 1929; 81:351-7.

- Raju TNK. The Nobel Chronicles. Lancet 1999; 353:2166.

- Wikipedia. Severo Ochoa. Available at: https://en.wikipedia.org/wiki/Severo_ Ochoa. Accessed November 30, 2017. 